Мельник Н. Г.

кандидат філологічних наук, доцент

КПІ ДВНЗ «Криворізький начіональний університет»

\title{
ДЕСТРУКТИВНА РОЛЬ НАДМІРНОГО ВТРУЧАННЯ СУСПІЛЬСТВА В ОСОБИСТЕ ЖИТТЯ ЛЮДИНИ (Т. МАЛЯРЧУК «МИ. КОЛЕКТИВНИЙ АРХЕТИП»)
}

У статті досліджуються проблеми співіснування творчої незалежної особистості і суспільства. Особлива увага звертається на відображення у творі психологічного обличчя сучасного міста, уніфікованості суспільних норм поведінки та спроби людини протистояти законам юрби. Провідними у творі є мотиви самотності та маргінальності непересічної особистості в реальному світі.

Ключові слова: особистість, суспільство, місто, мораль, проблема.

В статье исследуются проблемы сосуществования творческой независимой личности и общества. Особое внимание обращуается на отражение в произведении психологического облика современного города, унифицированности общественных норм поведения и попытки человека противостоять законам толnы. Ведущими в произведении являются мотивы одиночества и маргинальности незаурядной личности в реальном мире.

Ключевые слова: личность, общество, город, мораль, проблема.

The paper examines the problem of coexistence an independent creative individual and society. Particular attention is drawn to displaying psychological aspect of the modern city, uniformity of social behavior and attempts to resist human crowdslaws. The motives of outstanding personality's loneliness and marginality in the real world are leading in the book.

Key words: personality, community, city, morality problem.

Сучасна українська література - нова сторінка в історії національного письменства. Літературознавці вказують на їі різноманітність, багатоплановість, відповідність світовим мистецьким тенденціям [Андрусяк 2006: 5]. Це література, «котра щзе твориться, щуе не усталилися в критичній думц̧і та читаџ̧ькій уяві ї̈ головні персонажі, ї̈ вериинні здобутки й найдошкульніші втрати. Література, котру кожен читач, не кажучи вже про критика, схиль- 
ний потрактувати по-своєму, нерідко в корені інакще, ніж ие роблять інші читачі й критики» [Андрусяк 2006: 4].

На думку В. Даниленка, сьогодні Україна має високий літературний потенціал, проте, на жаль, «література розвивається зі своєю постколоніальною специфікою. I ия специфіка пов'язана з обмеженим простором функиіонування украӥнської мови, колоніальною ментальністю влади, виразників великого капіталу і широких верств населення, низькою культурою власників, топ-менеджерів $i$ журналістів засобів масової інформації, які не орієнтуються або поверхово орієнтуються в сучасній украӥнській літературі, не бачать в ній нічого иікавого...» [Даниленко 2008: 4]

Але, незважаючи на це, останні десятиліття відзначилися появою когорти успішних українських авторів, які заслужили читацькі симпатії. Однією з таких авторок є Т. Малярчук.

Творчість Т. Малярчук, зокрема досліджуваний нами твір, досить неоднозначно оцінюються сучасною літературною критикою.

Назва твору свідчить про авторську спробу аналізу психологічних моделей поведінки суспільства.

Як відомо, архетип є структуроутворюючим елементом колективного надсвідомого. Архетипи - це універсальні моделі несвідомої психічної активності, котрі спонтанно визначають людське мислення і поведінку.

Я. Голобородько досить критично оцінює твір і його назву зокрема. Аналізуючи збірку молодої письменниці «Як я стала святою», він зазначає: «Другий текст (досліджуваний нами твір H. M.) є необов'язковим - і для самої збірки, і для художнього смаку Тані Малярчук. У ньому чимало вразливих місць - від назви до якості художніх реалій. Назвою - "Ми. Колективний архетип" майже все сказано, що проблематично назвати достоїнством новітньої літератури. Художні реалії задумані в річищі гротескової поетики, проте їхня гротесковість виглядає інертно й навіть інфантильно, що не могло не позначитися на відсутності гостроти фрази, діалогів, колізії і врешті свіжої думки». 
Розуміючи, що кожен дослідник має право на власну думку, ми, проте, не погоджуємося 3 такою оцінкою твору та функції назви. Насправді, і назва, і зміст твору дають багато приводів для роздумів над проблемами психології колективу, місця людини в суспільстві, можливості співіснування непересічної, внутрішньо вільної людини із соціумом, що тисне на неї, змушує підпорядковуватися його законам.

Р. Харчук натомість зазначає, що «Т. Малярчук пише безсумнівно якісну прозу», а «критиці варто було б уважніше читати словесне плетиво авторки» [Харчук 2007: 63].

У творі йдеться про появу в місті двох незвичайних мешканок, приїзд яких відразу позбавляє місцевих жителів спокою.

Образ міста подано у творі досить своєрідно. Описуючи місто, до якого приїхали «новенькі», авторка наголошує на таких його рисах, як повна уніфікація мешканців, подібність одне до одного, відсутність рис, які б відрізняли одну людину від іншої. Втрата особистої свободи, необхідність підкорюватися «загальноприйнятим нормам поведінки» призвели до нівеляції специфічних ознак особистості: «Ми знаємо, щзо ми все одно разом. Нас об'єднує міська історія i архітектура, в нас подібні обличчя $і$ конституція тіла, ми говоримо одним діалектом і одним жаргоном, в нас спільна мафія $і$ спільна поліція, тому кожен з нас знає, щзо місто - це ми» [Малярчук 2006: 85]. Найжахливішим у творі $є$ те, що люди єдині у своїй пересічності, одноманітності, невибагливості, обмеженості інтересів і потреб.

Більше того, це навіть осмислюється ними як приналежність до певної елітної спілки на ймення «міщани», котра має нібито право диктувати всім іншим правила життя на їхній території. Авторка досить іронічно говорить про «духовний зв'язок» між мешканцями, що $є$ предметом їхнього захоплення та гордості: «Духовний зв'язок між нами, тобто традииї, етика, мораль, вищий за екскременти. Ми відчуваємо обов'язок звичаю бути мешканцями саме нашого міста. Арістотель назвав це етосом, $і$ ми йому віримо» [Малярчук 2006: 86]. У наведеному уривку яскраво проілюст- 
ровано парадоксальне поєднання понять духовного (духовний зв’язок) і фізіологічного (екскременти) плану, що є ознакою іронічного письма Т. Малярчук.

Цілком зрозуміло, що образ міста у творі - це модель національної свідомості українців. Авторка досить гостро говорить про наявність в українців здатності об’ єднуватися проти «чужинців».

Люди в місті звикли до пересічного, приземленого способу життя і навіть сприймають його як щасливе, гармонійне: «Якщо десь існує ідилія, то саме в наших сквериках: літо, спека, мухи, запах змішаних огірків $і$ помідорів, поту свого і чужого, своя $і$ чужа самотність, - у сквериках ми віддаємось легкому старінню, яке ніколи не викликає ностальгї̈ [Малярчук 2006: 86]. Змальовуючи цинізм юрби та їі байдужість до всього, авторка порушує проблему самотності сучасної людини. Перебуваючи в оточенні інших, особистість залишається усім байдужою і ніким не зрозумілою. Проте людей така ситуація повністю влаштовує.

Поява двох жінок, які вирізняються 3-поміж інших своїми зовнішністю та поведінкою, спочатку викликає шепіт здивування в місцевих, але природна звичка до лицемірства, подвійних стандартів змушує їх зробити вигляд, що «нас нічого не стосується $і$ поза нашими родинами нас нічого не цікавить» [ Малярчук 2006: 86].

Старша жінка, відрекомендувавшись, не впускаючи в подробиці особистого життя, доповідає: «Тварин не маємо, воду використовуємо мало, спати лягаємо біля десятої, музику гучно намагатимемося не вмикати» [Малярчук 2006: 87].

Таким чином, вона відкидає будь-які спроби втручання в іiі особистий простір. Приїжджих зустрічають із підозрою та недовірою. Головне питання, яке цікавить юрбу: «Чому вони приїхали в наше місто? Може від когось ховаються або щуось приховують?» [Малярчук 2006: 88]. Вчинки, припущення «слідчих» щодо причини приїзду та дивної поведінки «чужинок», відображають досить низький рівень моральних принципів життя мешканців містечка. Вони дозволяють собі беззастережно втручатися в особисте життя 
жінок, вирішують, чи доречно їм користуватися дорогою косметикою, цікавляться, скільки коштують їхні речі. Юрбу непокоїть, їй видається неприродним те, що жінки прагнуть і можуть жити інтелектуальним, високодуховним життям, цікавитися рідкісними книгами, спостерігати за зорями, дотримуються родинних цінностей, а їхні стосунки відрізняються щирістю та теплотою: «...вона слухає Раїду не так, як в нас доньки слухають своїх матерів; ...Катерина у вечір приїзу купувала для Раїди гранатовий сок... $і$ чотирнадиять персиків, а де ви бачили, щоб котрась з міських доньок купувала своїи матері персики»; «Вахтерка в університеті донесла, що на першому поверсі університету перед тим, як розлучитись, жінки завжди цілуються в щүічку, вона ж, вахтерка, не вірить в таку ніжну материнську любов...» (виокремлення наше - Н. М.) [Малярчук 2006: 89, 90, 92].

Очевидно, що існування поза межами морально-етичних цінностей стало для мешканців міста нормою, а вияв іншої життєвої концепції сприймається ними досить ворожо.

Моральна задуха в місті, аморальні стосунки між людьми, сліжка, доноси, змальовані авторкою, нагадують психологічну атмосферу творів Ф. Кафки. Особистість прямо залежить від грубої суспільної машини, і, щоб вижити, має з нею співіснувати. Проте, на відміну від кафківських, головні персонажі досліджуваного твору здатні зберігати свою внутрішню свободу і в таких умовах: «Виглядало, ніби їм більше нікого не треба, крім них самuх» [Малярчук 2006: 92]. Така позиція чужинок надзвичайно обурює «суспільну думку».

Місто у творі - це велика, груба машина, що пригнічує особистість, змушує іiі жити за своїми законами. Тому мешканці роблять висновок про те, що ці жінки «нічого корисного містові не принесуть» [ Малярчук 2006: 107].

Головна ідея твору висвітлена в іронічному ключі. Після смерті сина пані Завадської юрба раптом починає сумніватись у правильності обраного шляху: «Ми піддались легкому декадансу. 
Вперше почали лунати несміливі докори щуодо доцільності нашої діяльності, хтось сказав, що, можливо, «місто не потребує таких жертв, можливо, воно існує тільки для того, щцоб в ньому існували ми..? ...Невже особистість повинна цінуватись вище за колектив? Невже інтереси особистості превалюють над інтересами суспільства, а їхні дивацтва - над суспільною етикою і мораллю?» [Малярчук 2006: 107-108].

Проте досить швидко знаходиться речник «здорового глузду», який обгрунтовує необхідність саме такого способу життя: «Залишатись у незнанні - означає піддати небезпеці все місто! До того ж... НАМ ЦІКАВО» [Малярчук 2006: 108].

На думку авторки, гармонійні стосунки між суспільством i конкретною особистістю взагалі неможливі. Вони завжди протистоять одне одному. Це нормально, вважає Т. Малярчук, адже тільки коли особистість пройде цю війну, вона зрозуміє, ким вона $є$ насправді.

Письменниця в одному з інтерв'ю зазначила, що коли людина зможе жити так, неначе їй наплювати на суспільство, тоді суспільство прийме іiї на рівних умовах, оскільки суспільство не можна любити, з ним можна тільки співіснувати.

У творі присутня гра з прізвищами. Більшість із них відображають моральну сутність, ницість того чи іншого персонажа пані Грішева, пані Гріхова, Максим Голенький.

Усвідомивши, що жінки ніколи не погодяться жити за законами міста, мешканці приймають рішення про ізоляцію «дивачок», цинічно виганяючи їх: «Ми офічійно доводимо до вамого відома..., щуо далі залишатись в нашому місті ви не можете. Це суперечить законам не тільки нашого міста, а й людської моралі загалом... Сподіваємось, иановні жінки, ви оціните наму тактовність і поблажсливість, адже ми могли вас і заарештувати... Не знаємо, куди ви маєте намір податись. Однак, куди б ви не подались - пам'ятайте, щзо всі міста - подібні на наше, - ие копиці сіна, в яких не сховається жодна голка» [Малярчук 2006: 118]. 
Провідною у творі є думка про те, що люди не усвідомлюють неприродності такого існування, а тому й не прагнуть щось змінити. В одному 3 інтерв'ю Таня Малярчук також зазначила: «Ненормальність моїх героїв - це безуспішний спротив сучасному суспільству, яке, незважаючи на дивуючу багатоманітність, стає все більш конформістським та уніфікованим».

Таким чином, твір авторки змушує задуматися над важливою проблемою збереження особистої свободи, цілісності, безкомпромісності людини в умовах сучасного суспільства.

\section{БІБЛІОГРАФІЯ}

Андрусяк 2006 - Андрусяк I. М. Літпроцес в епоху перемін / Сучасна українська література кінця XIX ст. - початку XXI ст. / упрор. текстів, передм., підготовка навч.-метод. матеріалів І. М. Андрусяка. - К. : Школа, 2006. - С. 3-6.

Даниленко 2008 - Даниленко В. Г. Лісоруб у пустелі : Письменник і літературний процес. - К. : Академвидав, 2008. -352 с.

Малярчук 2006 - Малярчук Т. Як я стала святою / Т. Малярчук. - Харків : Фоліо, 2006. $-190 \mathrm{c}$.

Москалець 2006 - Москалець К. Весь цей блюз / К. Москалець // Критика. - 2006. - № 5. Харчук 2007 - Харчук Р. Найновіша підлітково-дитяча літературна альтернатива: С. Жадан, Л. Дереш, С. Поваляєва, I. Карпа, Т. Малярчук // Бібліотечка «Дивослова». - 2007. - № 7(25). - С. 50-64. 